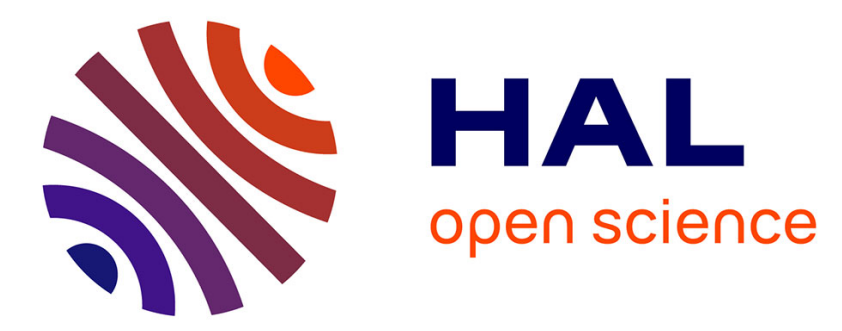

\title{
On-Chip Sample Preparation Using a ChipFilter Coupled to NanoLC-MS/MS for Bottom-Up Proteomics
}

Massamba Ndiaye, Ha Phuong Ta, Giovanni Chiappetta, Joelle Vinh

\section{To cite this version:}

Massamba Ndiaye, Ha Phuong Ta, Giovanni Chiappetta, Joelle Vinh. On-Chip Sample Preparation Using a ChipFilter Coupled to NanoLC-MS/MS for Bottom-Up Proteomics. Journal of Proteome Research, 2020, 19 (7), pp.2654-2663. 10.1021/acs.jproteome.9b00832 . hal-03086559

\section{HAL Id: hal-03086559 https://hal.science/hal-03086559}

Submitted on 30 Dec 2020

HAL is a multi-disciplinary open access archive for the deposit and dissemination of scientific research documents, whether they are published or not. The documents may come from teaching and research institutions in France or abroad, or from public or private research centers.
L'archive ouverte pluridisciplinaire HAL, est destinée au dépôt et à la diffusion de documents scientifiques de niveau recherche, publiés ou non, émanant des établissements d'enseignement et de recherche français ou étrangers, des laboratoires publics ou privés. 


\title{
On-chip sample preparation using a ChipFilter
}

\section{coupled to nanoLC-MS/MS for bottom-up}

\section{proteomics}

\author{
Massamba M. Ndiaye ${ }^{1}$, Ha Phuong Ta ${ }^{1}$, Giovanni Chiappetta ${ }^{1}$, and Joëlle Vinh ${ }^{1} *$ \\ ${ }^{1}$ Biological Mass Spectrometry and Proteomics (SMBP), ESPCI Paris, Université PSL, \\ CNRS, 75005 Paris, France
}

*Corresponding Author joelle.vinh@espci.fr

KEYWORDS: Proteomics, Microfluidic, ChipFilter, CFP, filter-assisted proteolysis, sample processing

ABSTRACT: Sample preparation is a crucial step in bottom-up proteomics. Analytical performances of bottom-up proteomics can be improved by the miniaturization of sample preparation. Many microfluidic devices have been designed in the field of proteomics, but many of them are not capable of handling complex samples and do not integrate the processing and digestion steps. We propose a ChipFilter Proteolysis (CFP) microfluidic device as a proteomics reactor for the miniaturization of protein sample processing and digestion steps, whose design is closely related to the experimental setup of Filter Aided Sample Processing (FASP), even if no denaturing surfactant is required. The microchip has two reaction chambers 
of $0.6 \mu \mathrm{L}$ volume separated by a protein filtration membrane in regenerated cellulose $(10 \mathrm{kD}$ cut-off) that will concentrate or retain large polypeptides and will release small molecules. Cell lysis, protein concentration, and rapid chemical or enzymatic treatment can be performed in the ChipFilter. Complex proteomic samples like yeast protein extract or whole human cells proteome have been successfully analyzed with our microchip. Compared to the membranebased commercial ultracentrifugation cartridge, our microfluidic device offered a better proteome coverage with ten times less starting material and eight times faster protocol duration.

\section{INTRODUCTION}

Mass spectrometry has become the method of choice for the direct detection of bio-organic molecules. It takes a primordial place in the analysis of proteins. Among different strategies, bottom-up proteomics relies on proteolytic peptides separation and sequencing by liquid chromatography coupled to mass spectrometry (LC-MS) after protein digestion. It is widely used because of its ease of use and robustness compared to top-down proteomics. However, protein processing for the bottom-up approach remains sample and time-consuming. In fact, after the recovery of the protein sample, it requires disulfide bonds reduction, cysteine residue alkylation to avoid bridge reformation, proteolysis of the proteins with an endoprotease, recovery of the proteolytic peptides before chromatographic separation and tandem mass spectrometry analysis. The experimental time is even more important when aiming at posttranslational modifications characterization. Sample-loss is also another key issue with several millions of cells routinely required for the bottom-up approach in order to recover at least 10 $\mu \mathrm{g}$ of protein extract. Indeed, the cytoplasm volume of Hela cells is about $0.94 \mathrm{pL}^{1}$ and a protein concentration of $1 \mathrm{E} 10$ per cell ${ }^{2}$ gives a theoretical value of $150 \mu \mathrm{g}$ total protein with 1E6 Hela cells for a 100\% extraction yield. The experimental values are estimated to be closer to $1 \mathrm{E} 9$ proteins per cell ${ }^{3}$, and this 10 -fold mismatch has been associated with both losses during 
sample handling and approximation during the calculation of the absolute concentration using pure proteomics signals ${ }^{2}$. The loss of sample during protein extraction, adsorption, protein or peptide purification, and detergent removal creates a gap between the high sensitivity of LCMS for peptide analysis and the minimum threshold required for the starting material ${ }^{2,3,4}$.

It is acknowledged that sample preparation and digestion steps in bottom-up proteomics need to be improved. Microfluidics is a logical strategy to address the sample and time-consumption problems since it has been well described for more than a decade ${ }^{5}$ that miniaturization is strongly correlated with an improvement of reaction kinetics ${ }^{6}$. Reinhoudt's group ${ }^{7}$ reports that the downscaling process increases the surface to volume ratio, the mass and heat transfer. Several microfluidic applications dedicated to proteomics have been developed in the past years, but unfortunately, these applications were not as successful as they were in genomics. This is explained by the complexity of the proteomic sample and analysis process. The objectives are to reduce the sample quantity threshold, accelerate sample processing and digestion. Freire et al. ${ }^{8}$ pointed out the fact that most microchip devices did not integrate the whole sample preparation process for bottom-up proteomics. Individual modules for on-chip digestion, pre-concentration, and clean-up, peptide or protein separation were separately available. Since that review, the situation has barely changed. Digestion is an important and unavoidable step in bottom-up proteomics but remains routinely time-consuming. Several microfluidic devices have been realized to reduce the time necessary for protein digestion. Microfluidic has been usually combined with immobilized enzyme reactors. Immobilized trypsin, for example, is reputed to have high digestion efficiency, low auto-digestion, and reusability ${ }^{9}$. A number of microfluidic devices dedicated to proteomic analysis has incorporated a solid phase with immobilized trypsin. This resulted in extremely fast digestion time from 10 minutes for cytochrome $\mathrm{C}^{10}$ to 15 seconds for a two standard protein mixture $(\mathrm{Mb}-\mathrm{BSA})^{11}$ with a sequence coverage from 80 to $95 \%$. More recently, Kecskemeti et al. 
presented a PDMS microchip with immobilized trypsin on to silica particles allowing rapid proteolysis in less than 10 seconds $^{12}$. Trypsin has also been immobilized directly on the PDMS walls for the digestion of tear proteins in 10 minutes $^{13}$. PMMA surface can be functionalized with trypsin-agarose for rapid digestion of standard protein in less than 4 seconds ${ }^{11}$. Unfortunately, these microchips perform only the digestion step. The other steps involving sample denaturation, reduction of disulfide bonds, alkylation to prevent artefactual disulfide bonds had to be performed off-chip. Furthermore, no protein pre-concentration is associated with these microchips that enables the sample to have high protein concentration and low contaminant levels for proper protein identification. However, some microfluidic devices are dedicated only to sample pre-concentration and clean-up. Those microchips are generally based on sample stacking, solid-phase extraction, and membrane filtration. Zhang et al ${ }^{14}$ integrated a nanocapillary array in a PDMS microchip dedicated to concentrate large molecules according to their charge. After preconcentration, analytes can be recovered for further processing or detected directly. Gasilova et al. ${ }^{15}$ used C18 functionalized magnetic beads integrated into a microfluidic device coupled to ESI-MS for peptide preconcentration. Microfluidic devices integrating a functionalized solid phase are promising devices for digestion, preconcentration or separation: Ethier et al. ${ }^{16}$ used SCX solid phase to make a proteomic reactor that allowed protein extraction, clean-up, preconcentration, and sample digestion. Mouse cells analyzed by the SCX proteomic reactor showed increased proteome coverage than in solution analyses. Unfortunately, such microfluidic devices encountered two main challenges. First, the incorporation of solid phase (particles) in the micro-system. Indeed, special designs have to be conceived to specifically introduce and retain solid supports. Second, the physico-chemical properties of the solid support should allow the retention of all the proteins in a sample despite the proteome complexity. 
An interesting non-microfluidic strategy was reported for bottom-up proteomics, relying on filter-assisted proteolysis (FAP) ${ }^{17}$. FAP method is based on the use of a molecular filtration membrane that retains high molecular weight (proteins) to allow easy removal of impurities and buffer component by centrifugation and has been widely used in the so-called Filter Aided Sample Preparation (FASP) ${ }^{18}$. While this method addressed the issues of sample loss and proteome coverage, it did not address the time-consumption limitation or the need to downscale samples in experiment ${ }^{19}$. Recently, Zougman et al. described S-traps or suspension traps ${ }^{20}$ approach that allows the digestion of complex samples in $30 \mathrm{~min}$. It provides the best balance of time, cost and performance when compared to in-solution and FASP digestion method ${ }^{21}$.

In the present work, we developed a straightforward microfluidic device integrating a molecular filtration membrane called a ChipFilter. It has been often contested that mixing is required to take full advantage of such a miniaturized device and agreeable modelization of enzymatic proteolysis kinetics has been proposed for such experimental conditions ${ }^{22}$. In our study, we designed a continuous flow mixing reactor which enables us to also increase the concentration-to-volume ratio thanks to the insertion of a $10 \mathrm{kDa}$ cut-off membrane.

Our system takes advantage of filter-assisted proteolysis (FAP) methods for easy preconcentration, purification and detergent removal steps; and from microfluidic systems for fast reaction kinetics, capacity to integrate multiple processes, minute sample processing, and automation. The filtration membrane allows the retention of high molecular weight species that includes the great majority of proteins. The membrane integration in the microchip during the microfabrication is easier than solid-phase packing into microfluidic devices which can be a very tedious task. Using a filtration membrane, every single step of protein processing for bottom-up proteomics can be done in one microfluidic device using the ChipFilter Proteolysis (CFP) strategy using a minimum of $1 \mu \mathrm{g}$ starting material. 


\section{MATERIALS AND METHODS}

Materials: PolyDiMethylSiloxane (PDMS) Sylgard 184 was purchased from Dow Corning, the SU-2000 photoresist from Microchem and the silicon wafer from Entegris. The following chemicals were selected at the highest available quality from the mentioned supplier. Iodoacetamide (IAM), dithiothreitol (DTT) and BSA protein standard were purchased from Sigma Aldrich. Bovine Serum Albumin-fluorescein isothiocyanate conjugate (BSA-FITC) was purchased from Fisher. Trypsin sequencing grade from bovine pancreas was purchased from Roche. LC-MS quality grade Optima acetonitrile (ACN) was purchased from Fisher Scientific. Trifluoroacetic acid (TFA), trichloroacetic acid (TCA), formic acid (FA), ammonium bicarbonate $(\mathrm{ABC})$ and urea were purchased from Fluka. The Milli-Q water was produced by an IQ 7000 from Merck Millipore. The filtration membrane inside the ChipFilter was cut from ultrafiltration PLGC cellulosic (regenerated cellulose) disks, MWCO 10,000 Da, Millipore. Glass beads used during yeast protein extraction by mechanical agitation and $\beta$ octanoylglucopyranoside have been purchased from Sigma Aldrich. Microcon-10kDa Centrifugal Filter Units with Ultracel-10 membrane were purchased from Merck Millipore.

FilterChip Design and Microfabrication: The PDMS microfluidic device is composed of two superimposed reaction-chambers (inner diameter $4 \mathrm{~mm}$, height $50 \mu \mathrm{m}$, volume $0,6 \mu \mathrm{L}$ each) assembled under a microscope. They are separated by a filtration membrane (diameter $4.3 \mathrm{~mm}$ ) slightly larger than the reaction chamber. $150 \mu \mathrm{m}$ diameter pillars inside the two chambers maintain the filtration membrane (see Figure 1). Fluorescence and transmission microscopy imaging was obtained with a confocal TCS SP8 confocal setup equipped with a Leica DMi8 inverted microscope (Leica microsystems) using dry objective *10 in XYZ-scan mode. The laser excitation was set to a band of $10 \mathrm{~nm}$ centered on $488 \mathrm{~nm}$ and the emission measured at $520 \mathrm{~nm}$. The images were analyzed with the Leica software LASX. 

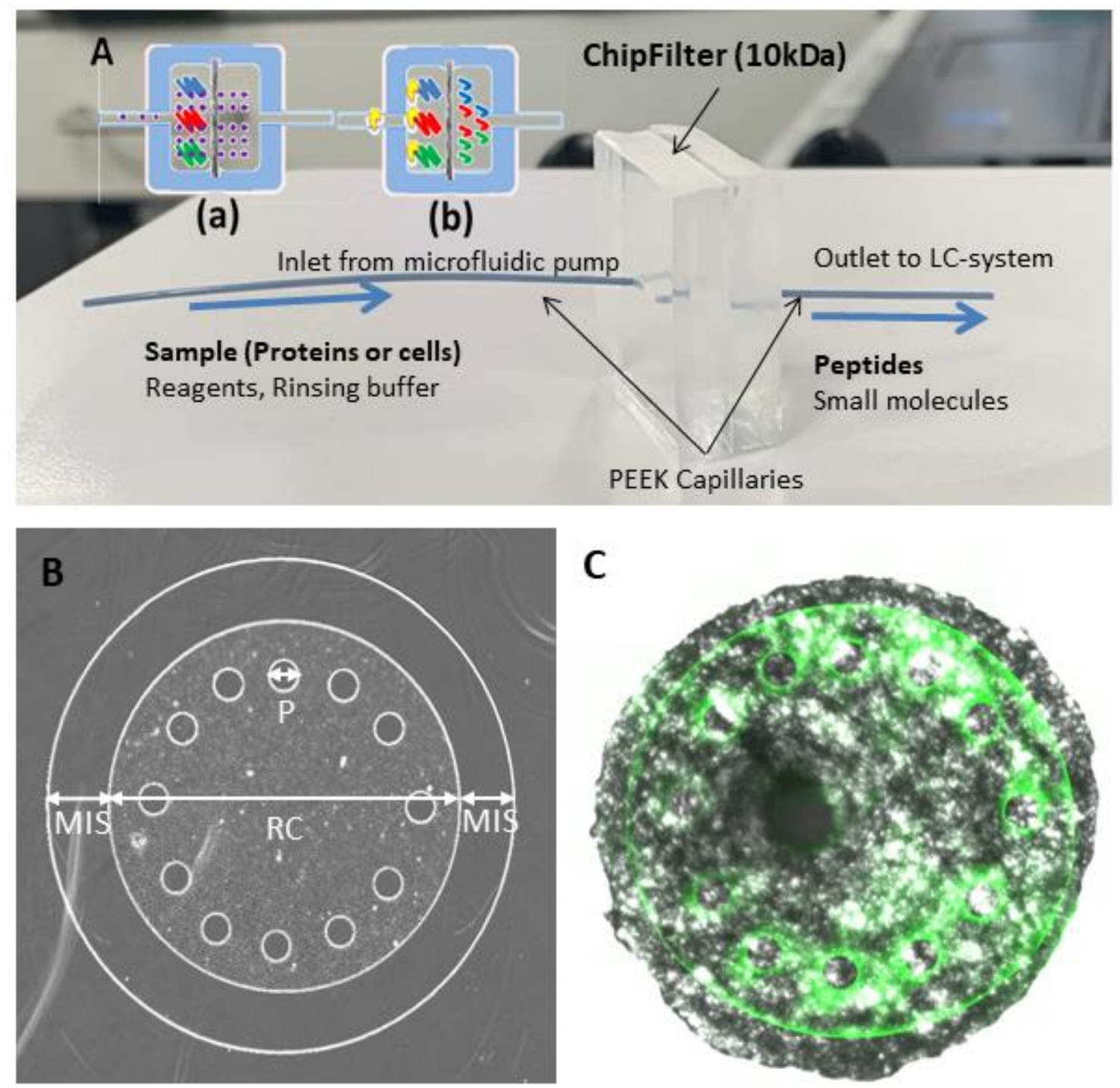

Figure 1: ChipFilter design. A) Picture of a ready to use ChipFilter with PEEK capillaries (70 $\mu \mathrm{m}$ i.d.) with the schematics of the (a) proteins loading step and (b) recovery of proteolytic peptides through the filter. (B) Confocal microscopy image depicting one symmetric part of the ChipFilter with the components P: Pillars, $\mathrm{D}=300 \mu \mathrm{m}, \mathrm{RC}$ : Reaction chamber, $\mathrm{D}=4 \mathrm{~mm}$, MIS: Membrane Integration structure $1=1.3 \mathrm{~mm}$ ) and $(\mathrm{C})$ Overlay of the transmission image of the PDMS-embedded $10 \mathrm{kDa}$ PLGC cellulosic membrane, and the fluorescence image of $1 \mu \mathrm{g}$ BSA-FITC loaded in the ChipFilter by confocal microscopy (Ex: 488 Em: 520)

A 3D master mold is used to ensure proper integration of the membrane. The patterns were designed with CleWin5 software, printed at high resolution $(25,400 \mathrm{dpi})$ on a photosensitive film by a photoplotter FilmStar-PLUS: 2 masks for each reaction chamber, with a 2 steps 
lithography for 3D molds. The mold is composed of 2 layers of negative photoresist on the silicon wafer. The first layer is a SU-2007 resin ( $8 \mu \mathrm{m}$ thickness, spin-coated at $2000 \mathrm{rpm})$, dedicated to the structure to incorporate the filtration membrane and to avoid any leakage of the reaction chamber (MIS, Figure 1B). After baking at $95^{\circ} \mathrm{C}$ for 2 minutes, the first mask features were transferred onto the wafer by photolithography using a UV-KUB3 aligner (LED, $40 \mathrm{~mW} / \mathrm{cm}^{2}, 160 \mathrm{~mJ} / \mathrm{cm}^{2}, 5$ seconds). After insolation through the mask 1 and post baked at $95^{\circ} \mathrm{C}$ for 2 minutes, a second photoresist is spin-coated on the first one. The second layer is a SU-2050 resin (50 $\mu \mathrm{m}$ thickness, spin-coated at $4080 \mathrm{rpm})$ dedicated to reaction chambers and pillars. The mask 2 is aligned to the patterns of the mask 1 using a UV-KUB3 aligner. The wafer is then exposed at LED light $(40 \mathrm{~mW} / \mathrm{cm} 2,160 \mathrm{~mJ} / \mathrm{cm} 2,4 \mathrm{~s})$. Finally, the developer removed the non-exposed part of the photoresist and reveal the 3D patterns. PDMS elastomeric polymer has been used to replicate the features from the mold with high precision.

PDMS Sylgard 184 is used for the replica molding. Using a two-component mix (base/curing agent, 10:1 (w/w)), the liquid pre-polymer is poured on the mold and cured at $70^{\circ} \mathrm{C}$ for $1 \mathrm{~h}$. After being exposed to an air plasma (20 W, $8 \mathrm{sccm} \mathrm{O} 2$ flow and 0.13 mbar pressure) for 1 min, the 2 PDMS parts are put in contact with the membrane between them. The membrane is deposited on the first chamber before the 2 PDMS parts assembly. It covers the first reaction chamber and the alignment of the two chambers is obtained under a microscope using alignment marks. A high-pressure contact between the 2 PDMS parts will allow a tight sealing around the filtration membrane. The whole setup is placed at $90^{\circ} \mathrm{C}$ for 15 minutes to enhance bonding.

Yeast extract. The cellular culture was maintained in a synthetic defined liquid media. The proteins were extracted from the Y252 yeast stem by mechanical agitation (beating) with glass beads $^{23}$. The proteins were extracted after cell lysis in $20 \%(\mathrm{v} / \mathrm{v})$ TCA $(600 \mu \mathrm{L})$ solution and $500 \mu \mathrm{L}$ silica beating beds. Five 30s duration beatings (Vortex-T Genie 2, Scientific Industries) 
spaced by $1 \mathrm{~min}$ (cooling on ice) was done to enhance the homogenization of the sample in a $2 \mathrm{~mL}$ microfuge tube. The supernatant was collected and centrifuged for 1 hour at 13,500 rpm. Proteins were rinsed with cold acetone and solubilized in urea $6 \mathrm{M}$, $\beta$-octanoylglucopyranoside $1 \%$, protease inhibitor, and Tris $-\mathrm{HCl} 150 \mathrm{mM} \mathrm{pH}=8.8$. Protein quantification was done by $\mathrm{BCA}$ assay.

Epithelial cells: HT29 colon adenocarcinoma cells (human intestinal epithelial cells) were obtained from the European Collection of Cell Cultures (Wiltshire, UK). Cells are cultured at $37^{\circ} \mathrm{C}$ in a $5 \% \mathrm{CO} 2 /$ air atmosphere in a Dulbecco's Modified Eagle Medium (DMEM, Fisher Scientific). After incubation, cells are washed with $5 \mathrm{~mL}$ PBS $1 \mathrm{x}$ and incubated at $37^{\circ} \mathrm{C}$ with trypsin-EDTA (Gibco) for 10 minutes. After centrifugation (3 min, $0.9 \mathrm{rcf}$ ), cells are washed three times with $3 \mathrm{~mL} \mathrm{NaCl} 0.9 \%$. During the 3rd wash, cells are counted on Malassez lamella (1/10 dilution). They are stored at $-20^{\circ} \mathrm{C}$ in $100 \mu \mathrm{L}$ of distilled water.

HT29 protein extracts were obtained by sonication in $10 \%$ aqueous TCA (final concentration). After centrifugation $\left(13,500 \mathrm{rpm}, 1 \mathrm{~h}, 4^{\circ} \mathrm{C}\right)$, the supernatant was removed and the protein pellet was rinsed with cold acetone and the proteins were solubilized in urea $6 \mathrm{M}$, $\beta$-octanoylglucopyranoside $1 \%$, protease inhibitor, and Tris- $\mathrm{HCl} 150 \mathrm{mM} \mathrm{pH}=8.8$.

For CFP analysis, the protein extraction of HT29 human cells has been realized inside the ChipFilter. First, the cells were loaded inside the ChipFilter. Second, $40 \mu \mathrm{L} 10 \%$ TCA solution was added at a flow rate of $2 \mu \mathrm{L} / \mathrm{min}$ and then $40 \mu \mathrm{L}$ of lysing buffer $(0.1 \mathrm{M}$ DTT, urea $6 \mathrm{M}$, $\beta$-octanoylglucopyranoside $1 \%$, protease inhibitor, and Tris- $\mathrm{HCl} 150 \mathrm{mM} \mathrm{pH}=8.8$ ) at the same flow rate. The protein proteolysis was finally performed in the same ChipFilter.

FAP proteolysis: The protein extract in urea $6 \mathrm{M}, \beta$-octanoylglucopyranoside $1 \%$, protease inhibitor, Tris $150 \mathrm{mM}$ and DTT $20 \mathrm{mM}$ was added in a Microcon and incubated for $2 \mathrm{~h}$ at $37^{\circ} \mathrm{C}$. The sample was then centrifuged at $14,000 \mathrm{~g}$. IAM $200 \mathrm{mM}$ was added and incubated for $1 \mathrm{~h}$ at $37^{\circ} \mathrm{C}$. The sample was then rinsed with $1 \mathrm{~mL} \mathrm{ABC} 50 \mathrm{mM}$ by ultracentrifugation 
$(14,000 \mathrm{~g})$. Trypsin digestion was performed at a ratio of 1:20 E/S in $150 \mu \mathrm{L}$ ABC $50 \mathrm{mM}, \mathrm{pH}$

8 for overnight digestion. The proteolytic peptides were then recovered by ultracentrifugation at $14,000 \mathrm{~g}$ for 1 hour.

Proteolysis automation: A flow-EZ pressure module, a flow controller, an M-switch (Fluigent) and the soft MAT (Microfluidic Automation Tool, Fluigent) were implemented for complete automation of the digestion protocol. The ChipFilter proteolysis protocols for mammalian cells and yeast protein extract are presented in tables 1 and 2

Table 1: ChipFilter proteolysis protocol applied to mammalian cells

\begin{tabular}{|c|c|c|c|}
\hline Steps & Description & Flow (D) et Volume (V) & Time (min) \\
\hline 1) Cell loading & Cell loading in the ChipFilter & $\begin{array}{c}\mathrm{D}=2 \mu \mathrm{L} / \mathrm{min}, \mathrm{V}=\text { sample } \\
\text { volume }\end{array}$ & $\begin{array}{l}\text { According to } \\
\text { sample volume }\end{array}$ \\
\hline 2) Cell rinsing & $\begin{array}{c}\text { Cell rinsing with acidic solution } \\
\text { TCA } 10 \%\end{array}$ & $\mathrm{D}=2 \mu \mathrm{L} / \mathrm{min}, \mathrm{V}=40 \mu \mathrm{L}$ & 20 \\
\hline $\begin{array}{l}\text { 3) Cell lysis and } \\
\text { disulfide bridges } \\
\text { reduction }\end{array}$ & $0.1 \mathrm{M}$ DTT in lysing buffer & $\begin{array}{c}\mathrm{D}=2 \mu \mathrm{L} / \mathrm{min}, \mathrm{V}=40 \mu \mathrm{L} \text { then } \\
\mathrm{D}=1 \mu / \mathrm{min}, \mathrm{V}=10 \mu \mathrm{L}\end{array}$ & 30 \\
\hline 4) Alkylation & $50 \mathrm{mM}$ IAM in lysing buffer & $\begin{array}{c}\mathrm{D}=2 \mu \mathrm{L} / \mathrm{min}, \mathrm{V}=40 \mu \mathrm{L} \text { then } \\
\mathrm{D}=1 \mu \mathrm{L} / \mathrm{min}, \mathrm{V}=10 \mu \mathrm{L}\end{array}$ & 30 \\
\hline 5) Rinsing & $\mathrm{ABC} 50 \mathrm{mM}$ & $2 \mu \mathrm{L} / \mathrm{min}, \mathrm{V}=30 \mu \mathrm{L}$ & 15 \\
\hline 6) Trypsin loading & $\begin{array}{c}\text { Trypsin solution } 0,1 \mu \mathrm{g} / \mu \mathrm{L} \text { in } \\
\text { TFA } 0.1 \%\end{array}$ & $\mathrm{D}=2 \mu \mathrm{L} / \mathrm{min}, \mathrm{V}=10 \mu \mathrm{L}$ & 5 \\
\hline 7) Trypsin activation & $\mathrm{ABC} 50 \mathrm{mM}$ & $\mathrm{D}=2 \mu \mathrm{L} / \mathrm{min}, \mathrm{V}=20 \mu \mathrm{L}$ & 10 \\
\hline $\begin{array}{l}\text { 8) Digestion and } \\
\text { Elution }\end{array}$ & $\mathrm{ABC} 50 \mathrm{mM}$ & $\begin{array}{c}\mathrm{D}=0.4 \mu \mathrm{L} / \mathrm{min}, \mathrm{V}=24 \mu \mathrm{L} \\
\text { then } \mathrm{D}=2 \mu \mathrm{L} / \mathrm{min}, \mathrm{V}=15 \mu \mathrm{L}\end{array}$ & 67 \\
\hline
\end{tabular}

Table 2: ChipFilter proteolysis protocol applied to protein extract

\begin{tabular}{|c|c|c|c|}
\hline Steps & Description & Flow (D) et Volume (V) & Time (min) \\
\hline 1) Sample loading & $\begin{array}{c}\text { Protein extract solution loading in } \\
\text { the ChipFilter }\end{array}$ & $\begin{array}{c}\mathrm{D}=2 \mu \mathrm{L} / \min , \mathrm{V}=\text { sample } \\
\text { volume }\end{array}$ & $\begin{array}{l}\text { According to } \\
\text { sample volume }\end{array}$ \\
\hline $\begin{array}{l}\text { 2) Disulfide bridges } \\
\text { reduction }\end{array}$ & $\begin{array}{c}20 \mathrm{mM} \text { DTT solution in ABC } 50 \\
\mathrm{mM}\end{array}$ & $\begin{array}{c}\mathrm{D}=2 \mu \mathrm{L} / \min , \mathrm{V}=40 \mu \mathrm{L} \text { then } \\
\mathrm{D}=1 \mu / \mathrm{min}, \mathrm{V}=10 \mu \mathrm{L}\end{array}$ & 30 \\
\hline 3) Alkylation & $50 \mathrm{mM}$ IAM in ABC $50 \mathrm{mM}$ & $\begin{array}{c}\mathrm{D}=2 \mu \mathrm{L} / \min , \mathrm{V}=40 \mu \mathrm{L} \text { then } \\
\mathrm{D}=1 \mu \mathrm{L} / \mathrm{min}, \mathrm{V}=10 \mu \mathrm{L}\end{array}$ & 30 \\
\hline 4) Rinsing & $\mathrm{ABC} 50 \mathrm{mM}$ & $2 \mu \mathrm{L} / \mathrm{min}, \mathrm{V}=30 \mu \mathrm{L}$ & 15 \\
\hline 5) Trypsin loading & $\begin{array}{c}\text { Trypsin solution } 0,1 \mu \mathrm{g} / \mu \mathrm{L} \text { in } \\
\text { TFA } 0.1 \%\end{array}$ & $\mathrm{D}=2 \mu \mathrm{L} / \mathrm{min}, \mathrm{V}=10 \mu \mathrm{L}$ & 5 \\
\hline 6) Trypsin activation & $\mathrm{ABC} 50 \mathrm{mM}$ & $\mathrm{D}=2 \mu \mathrm{L} / \mathrm{min}, \mathrm{V}=20 \mu \mathrm{L}$ & 10 \\
\hline $\begin{array}{l}\text { 7) Digestion and } \\
\text { Elution }\end{array}$ & $\mathrm{ABC} 50 \mathrm{mM}$ & $\begin{array}{c}\mathrm{D}=0.4 \mu \mathrm{L} / \mathrm{min}, \mathrm{V}=24 \mu \mathrm{L} \\
\text { then } \mathrm{D}=2 \mu \mathrm{L} / \mathrm{min}, \mathrm{V}=15 \mu \mathrm{L}\end{array}$ & 67 \\
\hline
\end{tabular}


NanoLC MS/MS: The proteolytic peptides were recovered in a trapping column (C18 Pepmap, $300 \mu \mathrm{m}$ i.d x 5mm length, ThermoFisher Scientific ) and analyzed in nanoLC MS/MS with a 2-hour gradient elution from 1 to $40 \% \mathrm{~B}$ (eluant A $2 \% \mathrm{ACN}$ in $0.1 \%$ aq. FA, eluant B $90 \% \mathrm{ACN}$ in $0.1 \%$ aq. FA v/v) on a $75 \mu \mathrm{m}$ i.d. $\mathrm{x} 50 \mathrm{~cm}$ length $\mathrm{C} 18$ column (Pepmap, ThermoFisher Scientific) using an RSLC U3000 system coupled to a nanoESI Q-Exactive HF mass spectrometer (ThermoFisher Scientific). The nanoESI (1.5kV) MS acquisition is operated in positive DDA mode using a Top20 method with automated switching between MS (350$1500 \mathrm{~m} / \mathrm{z}$, resolution $60 \mathrm{k}$ ) and MS/MS mode (resolution 15k). The data were analyzed with the MaxQuant software version 1.6.2.10 on Uniprot Yeast database (Uniprot, February 9th, 2013, 6651 entries) or on Homo sapiens (Uniprot, September 19th, 2018, 73.118 entries), with first search peptide tolerance at $20 \mathrm{ppm}$ and main search peptide tolerance at $4.5 \mathrm{ppm}$, using trypsin specificity with up to 2 miscleavages and 3 variable modifications: carbamidomethylation (C), oxidation (M), deamidation (NQ). The proteins identified following MaxQuant research have been filtered by Perseus ${ }^{24}$ software to remove those only identified by site, reverse and potential contaminant.

The Kyte-Doolittle hydrophobicity index has been calculated from a published package on R-Journal ${ }^{25}$.

Protein assay: BSA concentration was estimated using a UV spectrophotometer Nanodrop 1000 module proteinA280 (ThermoFisher Scientific) by reading the absorbance at $280 \mathrm{~nm}$. A sample volume of $2 \mu \mathrm{L}$ has been used for BSA measurement. Yeast protein extract concentration was determined by micro BCA protein assay kit (Fisher Scientific).

The quantities indicated in this document correspond to the starting material quantities. They are expressed in cell number when the protein extraction is performed in the ChipFilter and in $\mu \mathrm{g}$ of protein extract when the extraction is performed outside the ChipFilter. Before the nanoLC MS/MS analysis, proteolytic peptides are concentrated on a C18 media with an 
estimated maximal retention capacity of $5 \mu \mathrm{g}$ (Zip-Tip pipette tips, Millipore). The eluted solutions are dried (SpeedVac concentrator) and peptides resuspended in $2 \mu \mathrm{L}$ aqueous TFA $0.1 \%(\mathrm{v} / \mathrm{v})$. The $2 \mu \mathrm{L}$ volume is then injected for nanoLC MS/MS analysis. This is valid for

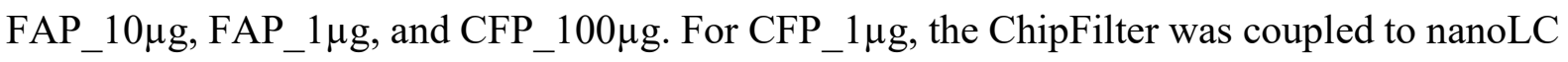
with the total amount of proteolytic peptides directly trapped and analyzed.

\section{RESULTS AND DISCUSSION}

Validation of the experimental setup: CFP method is composed of several steps starting from sample loading (protein extract or whole cells) into the microchip by pressure-driven flow, followed by retention of proteins on the membrane while small molecules and salts are washed off, i.e., concentrate and desalt the sample. Protein extraction and/or proteolysis was easily performed inside the microfluidic device since the ChipFilter holds up to $150^{\circ} \mathrm{C}$ even in acidic solutions. Moreover, protein reduction, alkylation, and labeling were to be done by adding the corresponding reagents (DTT for reduction and IAM for carbamidomethylation). As the molecular masses of the reagents were below $10 \mathrm{kDa}$ cut-off of the filtration membrane, the reagents in excess were completely removed by rinsing the proteins with a washing buffer. Proteolytic digestion was finally performed by flowing the trypsin solution into the reaction chamber. Like proteins, intact trypsin molecules were retained on the membrane so the digestion could be performed in a small volume above the membrane $(0.6 \mu \mathrm{L})$. Sample and trypsin confined in such a small volume allowed rapid and effective digestion of the complex protein extract. The proteolysis aims at covering as much as possible proteome of the sample and ultimately the sequence of each protein, thus lowering the risk of false-negative and falsepositive results. Since the sizes of generated tryptic peptides in bottom-up proteomics are between 500 and $3000 \mathrm{Da}$, they passed through the $10 \mathrm{kDa}$ filtration membrane to be recovered for LC-MS analysis (Erreur ! Source du renvoi introuvable.A, (a) and (b)). 
The design of the CFP device integrated a regenerated cellulose molecular membrane into a PDMS microchip. PDMS presents the advantage to irreversibly seal to itself after plasma exposure. This advantage was crucial for the ChipFilter sealing to avoid any sample leak and for passage of the sample through the filtration membrane and not around. Fluid transport and flow-rate inside the microchip were controlled by an external pump and a fluid controller. Different flow-rate values were applied depending on the steps of the digestion protocol. A maximum flow rate of $3 \mu \mathrm{L} / \mathrm{min}$ and a maximum pressure of 500 mbar could be used reliably.

To check if proteins are efficiently retained in the reaction chamber by the membrane, the protein concentration of BSA standard solution $(500 \mu \mathrm{L}, 1 \mathrm{mg} / \mathrm{mL})$ was monitored before and after passing through the ChipFilter membrane by UV absorption. The absorbance of the solutions was measured at $280 \mathrm{~nm}$ using a Nanodrop1000. No UV absorbance was detected at the exit of the device confirming the absence of leaks. When the solution in the reaction chamber was recovered by reverse percolation, an UV absorbance slightly lower (89\%) than the starting solution was detected (see Suppl Figure S1). We performed the same protocol using lug of Bovine Serum Albumin-fluorescein isothiocyanate conjugate (BSA-FITC) to test the proper sealing and recovery of the ChipFilter. Through the transparent PDMS volume, the fluorescence of BSA-FITC demarcated the upper reactor chamber and the 12 pillars and demonstrated the effective sealing between the two PDMS parts (Figure 1C). The filter is embedded in the PDMS interface and is detected as an opaque material. The dark spot in the center is the punched hole for the inlet capillary. Fluorescence confocal microscopy allowed the localization of BSA-FITC during sample loading (Suppl. Figure S2) and highlighted a strong limitation due to non-negligible sample loss during specific sample handling for recovery (Suppl. Figure S3).

The proteolysis of BSA in the ChipFilter was tested for different amounts of starting material to evaluate the limit of detection in off-line conditions (see Table 3). In this specific test, CFP 
was performed off-line and from the total elution volume of $15 \mu \mathrm{L}$. In parallel FAP was performed on $100 \mu \mathrm{L}$ of BSA at $1 \mu \mathrm{g} / \mu \mathrm{L}$. For each nanoLC-MS/MS analysis (with analytical triplicates), $2 \mu \mathrm{L}$ out of the total elution volume were directly injected. The results were compared in terms of percentage of BSA sequence coverage and the total number of distinct sequences, regardless of any chemical or post-translational modification. First of all, CFP was validated and demonstrated interesting performances, when compared to FAP for equivalent injected amounts. Then we could suspect a threshold between $400 \mathrm{ng}$ and $100 \mathrm{ng}$ total protein starting amount because the sequence coverage and the number of identified proteolytic peptides dropped.

Table 3: BSA proteolysis in ChipFilter. The maximum injected amount in equivalent BSA is estimated according to the ratio injection to elution volumes and the starting amount of undigested BSA

\begin{tabular}{|c|c|c|c|c|c|}
\hline Protocol & $\begin{array}{c}\text { Starting } \\
\text { amount }(\mu \mathrm{g})\end{array}$ & $\begin{array}{l}\text { Elution vol. } \\
\qquad(\mu \mathrm{L})\end{array}$ & $\begin{array}{l}\% \text { Sequence } \\
\text { coverage }\end{array}$ & $\begin{array}{l}\text { \# distinct } \\
\text { sequences }\end{array}$ & $\begin{array}{c}\text { Max injected } \\
\text { amount (equ. BSA) }\end{array}$ \\
\hline \multirow[t]{4}{*}{ CFP } & 10 & \multirow[t]{4}{*}{15} & 90 & 93 & $1.3 \mu \mathrm{g}$ \\
\hline & 0.4 & & 80 & 82 & $53 \mathrm{ng}$ \\
\hline & 0.1 & & 30 & 18 & $13 \mathrm{ng}$ \\
\hline & 0.03 & & 20 & 12 & $4.0 \mathrm{ng}$ \\
\hline FAP & 100 & 100 & 72 & 52 & $2.0 \mu \mathrm{g}$ \\
\hline
\end{tabular}

Different rinsing conditions were tested with $\mathrm{ABC} 50 \mathrm{mM}$, milli-Q water, and a detergent solution ( $\beta$-octanoyl glucopyranoside, $1 \%$ ). None of them affected the efficiency of recovery. However, we found that the pressure and the flow rate may affect protein retention on the membrane. The maximum flow rate and pressure reliability were found at $3 \mu \mathrm{L} / \mathrm{min}$ and at 500 mbar respectively. The experimental conditions are detailed in Table 2 for protein extract. They have been adapted from whole-cell analysis in Table 1. Higher values of the flow rate or the pressure could lead to a reduced presence of proteins in the flow-through. 
Automation of CFP: Since CFP was proven to be fully operational with BSA, it was further applied to the characterization of the total extract of yeast proteins and compared with the FAP method. The microchip was then interfaced for automation using a flow-EZ pressure module, flow controller and M-switch ("Figure 2). This setup was operated using the software "MAT" (see Material and Methods) for complete automation of the protocol. The outlet of the ChipFilter was connected to the sample loop of the LC autosampler to perform the online nano LC-MS/MS analysis of the peptide mixture generated by the CFP.

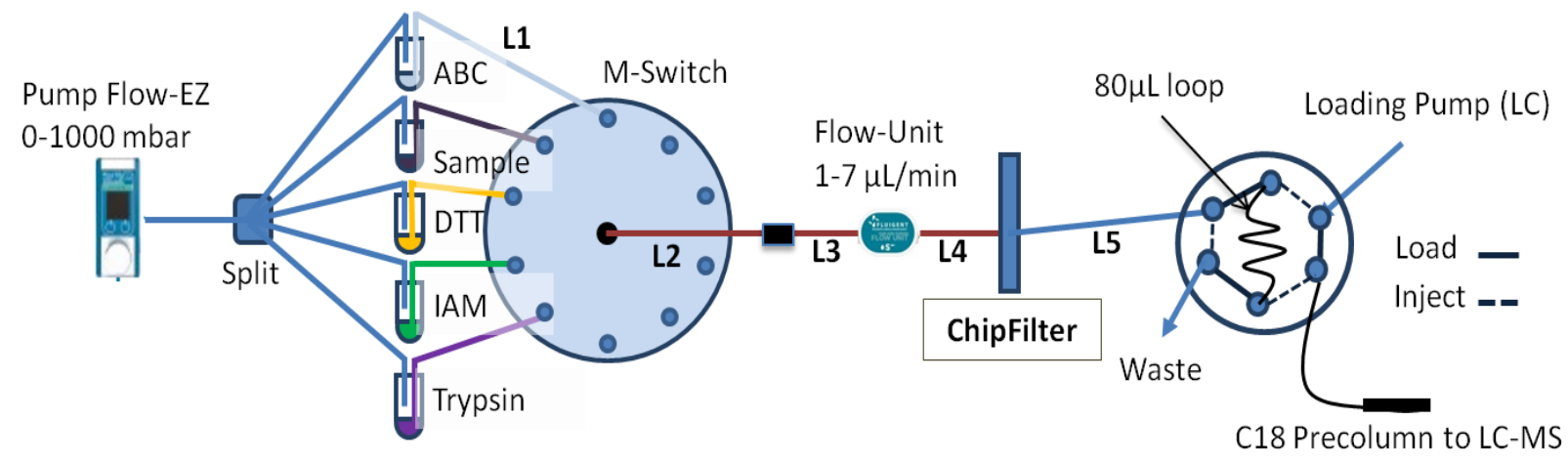

"Figure 2: Automated setup for CFP coupled to nanoLC MS/MS. Using the microfluidic pump (Flow-EZ) the sample, the dithiothreitol (DTT), the iodoacetamide (IAM), the trypsin (TRP) and the $\mathrm{ABC}$ buffer were selected with the M-Switch before injection in the ChipFilter under controlled flow rates using a feedback loop (Flow Unit). Eluted peptides are loaded in an $80 \mu \mathrm{L}$ loop fitted in the injection valve of the nanoLC autosampler before injection and concentration on a C18 precolumn for subsequent nanoLC MS/MS analysis. All the capillaries used in this work are PEEK (PolyEtherEtherKetone). The capillaries (L1 to L5) dimensions can be found in Supp. Table S1"

Comparison of CFP and FAP using the proteome of the Y252 strain: To assess the sample loss in our experimental setup, different amounts of raw yeast cell protein extracts were processed and analyzed. According to our validation criteria, starting with $10 \mu \mathrm{g}$ of raw protein extract, 2406 proteins were unambiguously identified, while 1485 proteins were identified on 
average $(\mathrm{n}=3)$ starting from $1 \mu \mathrm{g}$ of protein extract, and 1185 proteins from $500 \mathrm{ng}$ (see Supplementary Figure S14).

The results obtained with $1 \mu \mathrm{g}$ of protein extract were then compared to those of the classical FAP method using 1 and $10 \mu \mathrm{g}$ of protein extract respectively. In total 1815 proteins were unambiguously identified from $1 \mu \mathrm{g}$ of protein extract as a starting material by CFP method and was compared with 1652 proteins identified from $10 \mu \mathrm{g}$ and 95 proteins identified from $1 \mu \mathrm{g}$ of starting material by FAP method. We decided to compare the proteome and sequence coverages between the two most comparable results obtained with CFP from $1 \mu \mathrm{g}$ of protein and FAP from $10 \mu \mathrm{g}$ of protein ("Figure 3). One major factor is in the digestion time: we decided to consider $1 \mathrm{~h}$-incubation for CFP and rapid FAP, and $18 \mathrm{~h}$ for conventional FAP. We will also discriminate between the peptides that are generated during the first hour of incubation and the peptides that are generated overnight after a 1h-incubation. All the experiments were performed in triplicate using three separate extracts for each series of experiments and each digestion was realized in an independent and new device. All at once, CFP allowed decreasing drastically both the sample processing duration and the amount of required starting material that led to improved proteome coverage. Even if the absolute number of identifications with only 1 peptide is similar between the CFP $(1 \mu \mathrm{g})$ and FAP $(10 \mu \mathrm{g})$ protocols, our results suggested a trend toward a higher percentage of proteins identified in FAP with only 1 peptide (p-value $=0.07$ for Student-test with 273 proteins or $18.3 \%$ in CFP, and 278 proteins or $20.3 \%$ in FAP). On the contrary, the number of proteins identified with more than 10 peptides was unambiguously higher for the CFP ( $\mathrm{p}$-vale $=2.10^{-4}$ for Student test, 338 proteins or $22.8 \%$ instead of a maximum of 217 proteins or $15.9 \%$ for FAP), leading to more robust identifications, wherein protein coverage is a key parameter to differentiate proteoforms and subclasses of proteins or to detect endogenous proteolysis and protein maturation. 


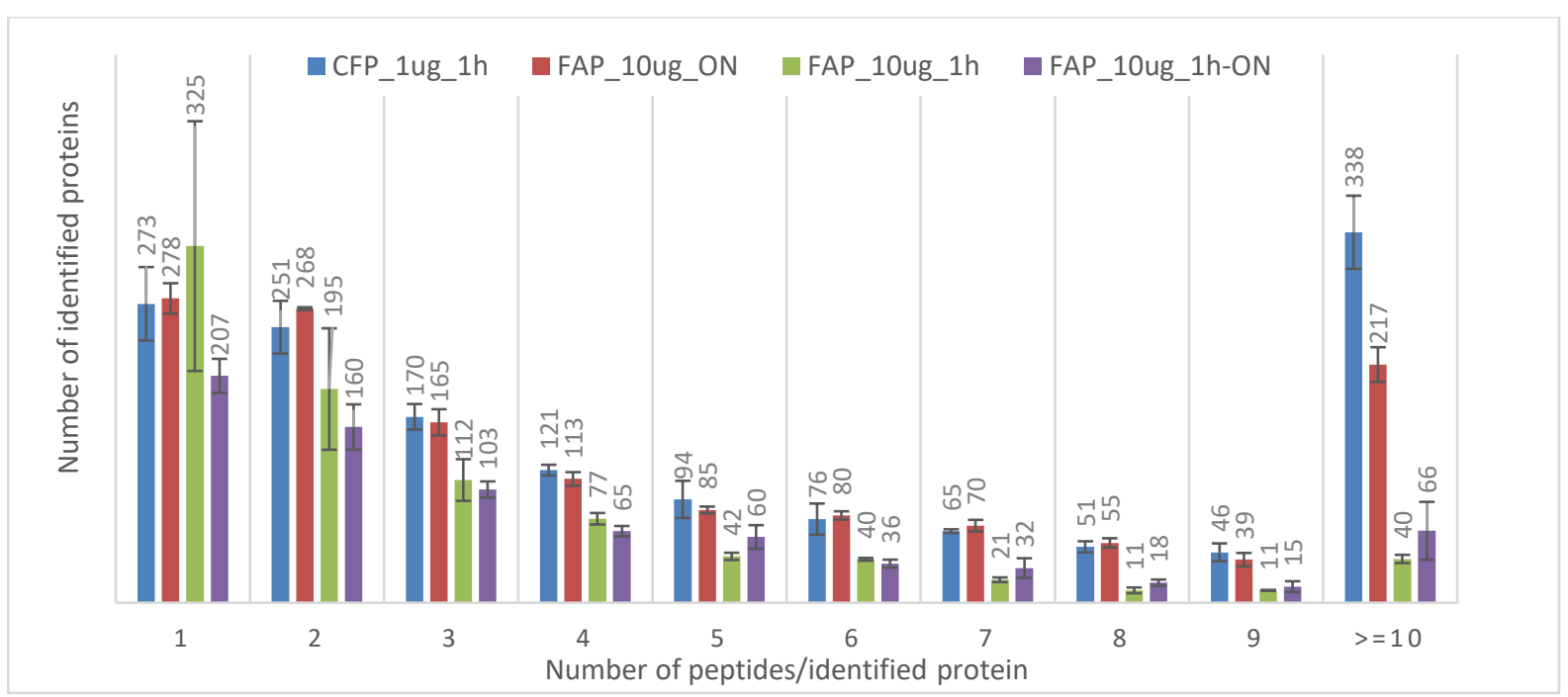

"Figure 3: Comparison between CFP (on-chip digestion) and FAP methods for yeast protein extract: Averaged number of protein identifications $(n=3)$ is according to the number of sequenced proteolytic peptides in CFP vs. FAP, that uses CFP with $1 \mu \mathrm{g}$ of extract incubated for 1h (CFP_1ug_1H), FAP with 10 $\mu$ g of extract incubated overnight (FAP_10ug), FAP with $10 \mu \mathrm{g}$ of extract incubated for $1 \mathrm{~h}\left(\mathrm{FAP} \_10 \mathrm{ug} \_1 \mathrm{H}\right)$ and new identifications obtained from 10 $\mu \mathrm{g}$ of extract incubated overnight after removal of proteolytic peptides by filtration after incubation for $1 \mathrm{~h}$, and addition of $100 \mu \mathrm{L}$ of buffer ABC (FAP_10ug_1H-ON)"

To further evaluate our setup, we compared the percentage of detected peptides with 0,1 or 2 miscleavages between CFP and FAP. Overnight FAP provided higher sample coverage among the FAP methods. CFP analyses showed that $65 \%$ of the detected peptide had no miscleavage while $29 \%$ and $6 \%$ had 1 and 2 miscleavages respectively. Overnight FAP analyses showed that $85 \%$ had no miscleavage while $14 \%$ and $1 \%$ had 1 and 2 miscleavages respectively ("Figure 4). CFP produced in percentage more peptides with miscleavages and this could be related to the shorter digestion times. This effect could be a double edge sword for protein identifications as it leads to the detection of short sequence portions usually missed because of their low mass and specificity, but improves protein sequence coverage. Despite this observation regarding the relative number of identifications, it should be noted that the absolute 
number of identified peptides is globally higher with CFP in any number of miscleavages. However, the peptide mass distribution remained similar to the two protocols (see Suppl. Figures S6 and S7).

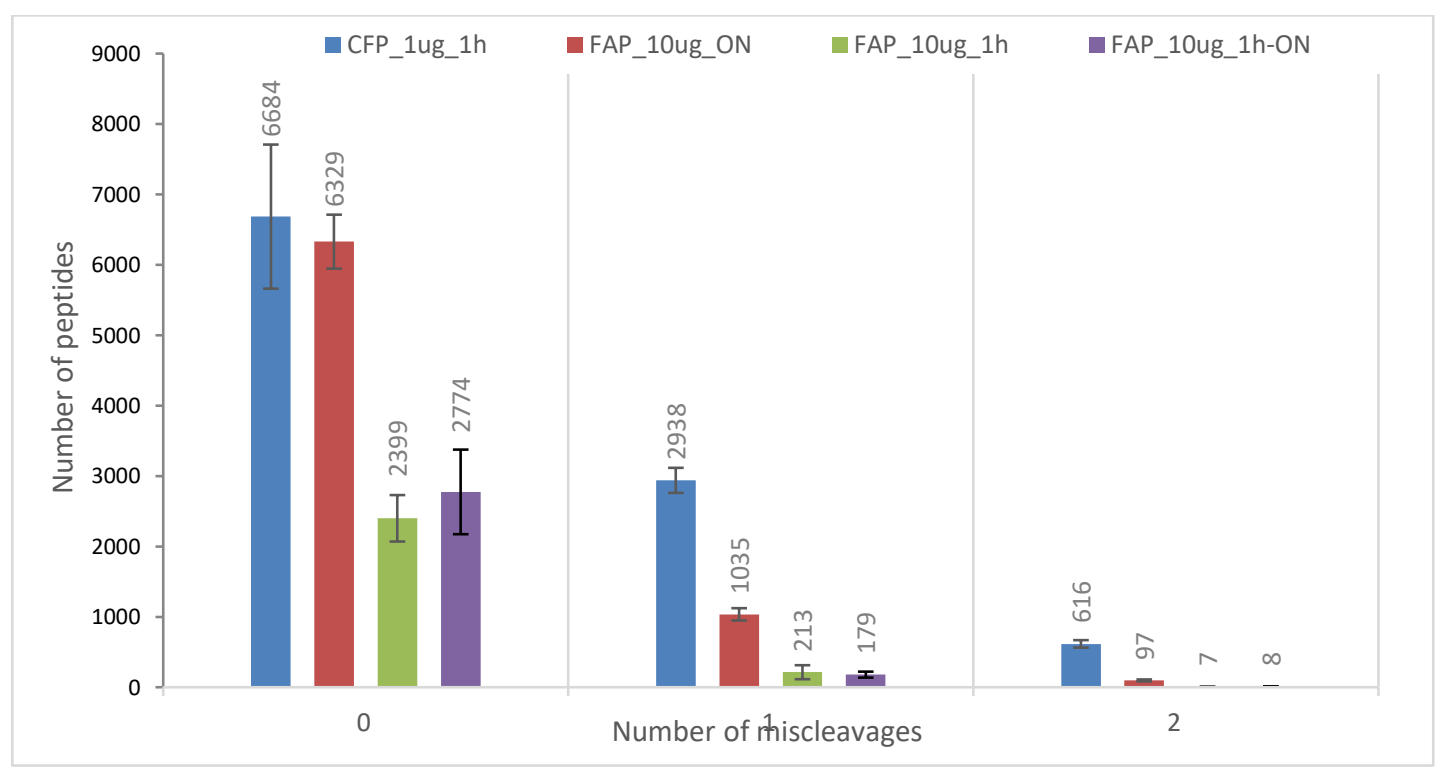

"Figure 4: Comparison of the number of identified peptides with 0,1 and 2 miscleavage(s) between CFP with $1 \mu \mathrm{g}$ yeast extract and FAP with $10 \mu \mathrm{g}$ yeast extract. (n=3)"

We then evaluated the protein sequence coverage considering the peptides identified with 0 , 1 and 2 miscleavages in each method. Looking at the differences in terms of the number of identifications, it was then combined with the physicochemical properties of validated peptides. Indeed, the PDMS surface is hydrophobic and is prone to non-specific adsorption of proteins and hydrophobic peptides. To attenuate this effect, the PDMS device was treated by $\mathrm{O}_{2}$ plasma oxidation, as its effect has been reported to last for a few hours ${ }^{26}$. The PDMS surface of the ChipFilter had not received any other hydrophilic treatment than the plasma exposition during the bonding step. For our experiments, the ChipFilter was fabricated extemporaneously just before the sample processing to take advantage of the hydrophilic property of plasma treated-PDMS lasting for a few hours just after $\mathrm{O}_{2}$ plasma exposition. To evaluate the efficiency of PDMS plasma pre-treatment we compared some features of the peptides identified with or without miss cleavages in CFP and FAP. In total 4565 peptides without 
miscleavages were exclusively identified by CFP, while 2477 were exclusively identified by the FAP method ("Figure 5). Only $44 \%$ of the peptides were common. Looking at the protein level, however, $70 \%$ of the proteins were identified with both protocols (see Suppl. Figure S4).

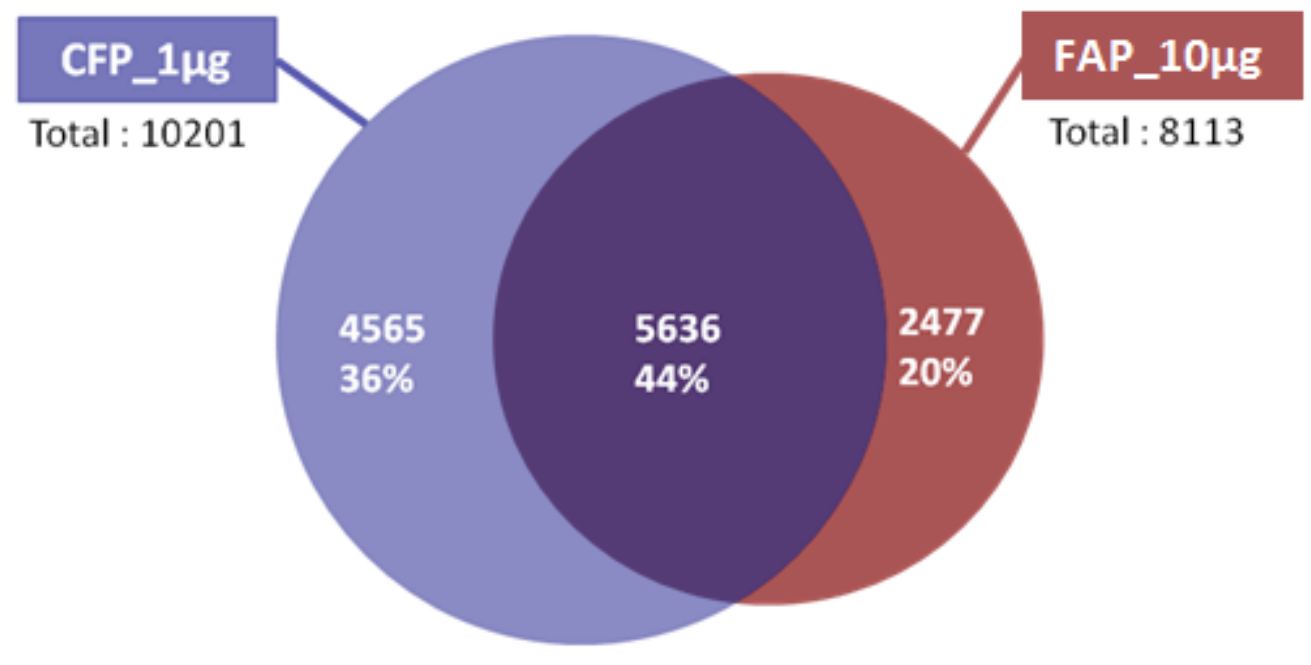

Total : 12678

"Figure 5: Distribution of identified peptides sequences without miscleavage from CFP $1 \mu \mathrm{g}$ and FAP $10 \mu \mathrm{g}$ - method BioVenn ${ }^{21}$ "

Considering the Kyte-Doolittle hydrophobicity index, the hydrophobic properties of peptides identified exclusively in each method have been compared ("Figure 6A). A two-sample t-test (Student) showed that the mean of hydrophobicity index for peptides exclusively identified by CFP is greater than the mean of those exclusively identified by the FAP method. This is not the case when considering the complete set of peptide identifications (common or specific to one method, see Suppl Figure S8). The absence of permanent hydrophilic PDMS pre-treatment did not bias the selectivity toward the hydrophobic peptides compared to the FAP method. We also evaluated if CFP induced a bias in the molecular mass range of identified peptides. For this we compared the molecular mass of the peptides identified with CFP and/or FAP. We observed that if the number of peptides identified with CFP is greater in every mass interval as compared to the FAP method, the distributions are slightly biased towards the high mass range 
in CFP ("Figure 6B). This has to be correlated with the higher number of miscleavages detected in CFP as it has been discussed previously.

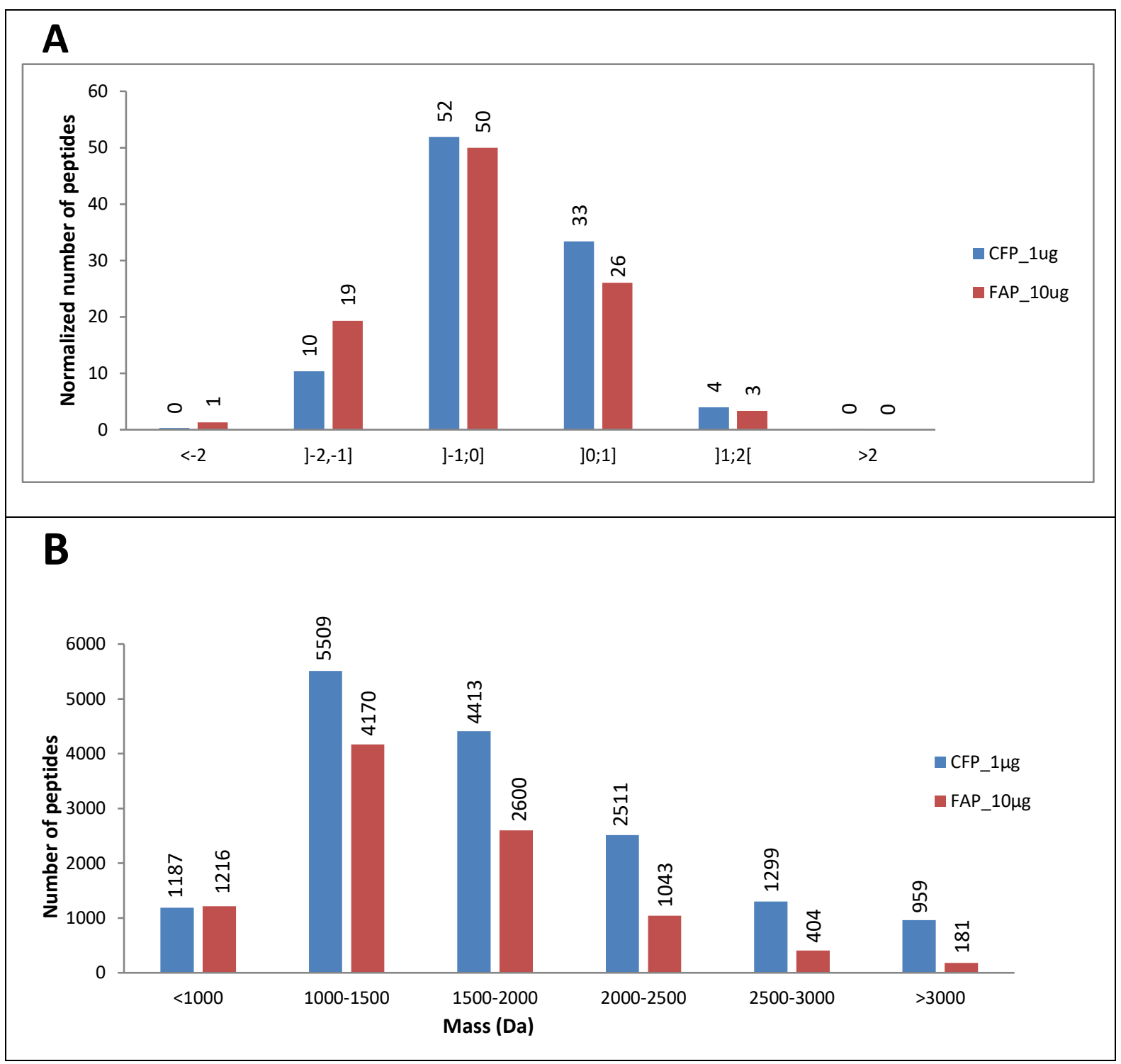

"Figure 6: A) Kyte-Doolittle Hydrophobicity Index of peptides exclusively identified by CFP_1 $1 \mu \mathrm{g}$ and FAP_10 $\mu \mathrm{g}$; B) Molecular mass distribution of peptides identified by CFP_1 $1 \mu \mathrm{g}$ and FAP_10 $\mu \mathrm{g}$. The Kyte-Doolittle index has been calculated from a published package on RJournal $^{25}$

Looking at the gene ontology for cellular compartment classification demonstrated that the cytoplasm, the mitochondrion, phosphoproteins, and ribosomal proteins were the most enriched compartments. The CFP digestion allowed the identification of a larger number of 
proteins in each cellular compartment than the FAP method, but the distribution is similar in both protocols (Supp. Figure S5, Table S3).

On-chip cell lysis CFP nanoLC MS/MS: To minimize sample loss, sample handling should be limited and the direct approach for that is to include the cell lysis and protein extraction steps in the same reactor. If this is not easily implemented with yeast cells due to the structure of their membrane, the smooth membrane of mammal cells such as human colon adenocarcinoma cell line HT29 can be disrupted using chemical cell lysis. The protein extraction and proteolysis have been implemented inside the ChipFilter using 28,000 HT29 cells leading to 4081 protein identifications $(n=3)$. The cell lysis and protein processing realized both in the ChipFilter lead to a bigger proportion of peptides with miscleavages compared to protein processing realized in the ChipFilter with the same digestion (Supp. Figure S9). The subcellular compartments are evenly represented when compared to a classical protein extraction outside the ChipFilter (Supp. Figure S10).

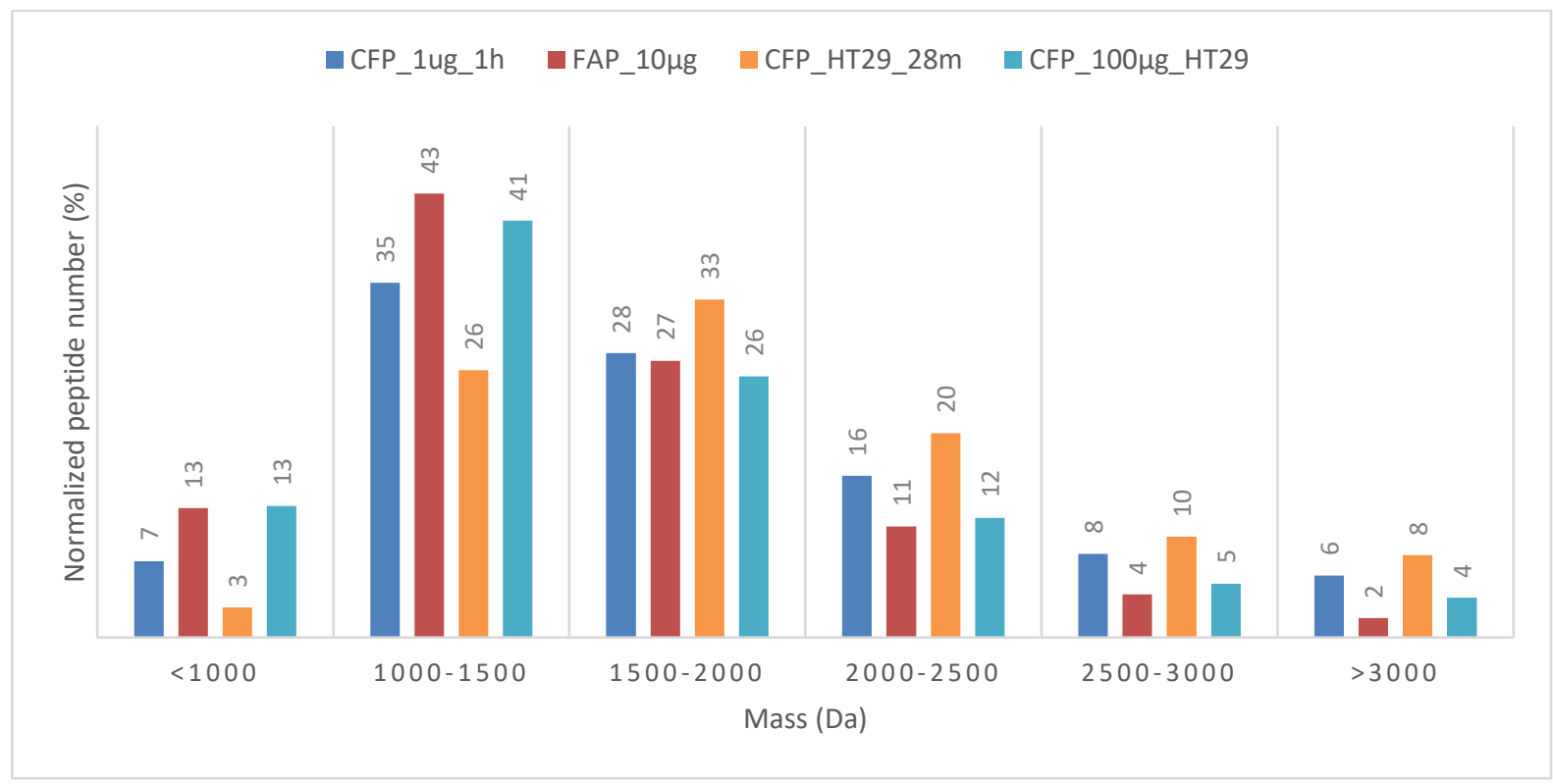

"Figure 7: Normalized distribution of the number of peptides identified by CFP_1 $1 \mu \mathrm{g}$,

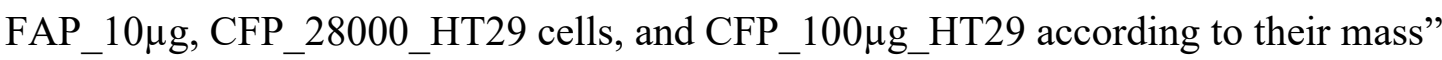


The on-chip cell lysis leads to a peptide mass distribution shift towards the higher mass range as shown in "Figure 7, which compares the normalized distribution of peptides identified with CFP_1 $1 \mu \mathrm{g}, \mathrm{FAP} \_10 \mu \mathrm{g}$, and on-chip cell lysis, but with the Kyte-Doolittle index distribution unaffected (Suppl. Figure S12). An improved proteome coverage is observed when protein processing is realized inside the ChipFilter compared to FAP (Suppl. Figure S11). This could be explained by the larger volumes used for peptides' recovery and the additional step for preconcentration. That improvement is even better when the cell lysis is performed inside the ChipFilter. The reproducibility of CFP has been evaluated using identified protein intensities, by scatter plot function (Perseus). Pearson correlation coefficient has been estimated for 0.5 $\mu \mathrm{g}, 1 \mu \mathrm{g}$ and 28,000 cells starting materials $(\mathrm{n}=3)$. We observed a good reproducibility $(\mathrm{r} \approx 0.94)$ with protein extracts or cells as starting material (Suppl. Figure S13). This is an illustration of the advantages of sample preparation integration in the field of proteomics.

\section{CONCLUSION}

We propose the ChipFilter Proteolysis (CFP) method as a simple device for rapid protein processing including at least five main steps: cell lysis, preconcentration, sample clean-up, reduction, alkylation and enzymatic proteolysis in the same reactor. The design for microfabrication of the ChipFilter allows easy and robust integration of a molecular filtration membrane in PDMS microchip, using soft lithography and replica molding. The efficient protein retention and proteolysis on the membrane have been validated with the BSA standard solution. Then, CFP has been applied to yeast protein extract. In comparison to the classical overnight FAP method, CFP allowed reaching better proteome and protein sequence coverage from at least ten times less starting material to work in one hour. The digestion protocol with ChipFilter reduced significantly the amount of sample and the required time for such in depth 
proteome analysis. CFP is an example of miniaturization that can handle integrated complex sample processing. The on-chip cell lysis has been implemented in order to minimize sample loss. This allows a good proteome coverage from 28,000 epithelial cells. It also proves the efficiency of chemical lysis inside the ChipFilter which will contribute to improving the sensitivity of the device. Moreover, the ChipFilter could be directly coupled to nano LCMS/MS for the proteolytic peptides to be fractionated and sequenced in an integrated and miniaturized automated platform.

Further work may be done to reach a higher sensitivity such as decreasing the inner diameter of reaction chambers. More efficient and stable PDMS surface treatment could be used to enhance sample recovery. On-site peptide trapping can be also implemented just below the $10 \mathrm{kDa}$ membrane to minimize sample loss by nonspecific adsorption. Another very promising application is the possibility to perform sample derivatization for specific moieties targeting or to adapt our device for functionalized membranes.

\section{SUPPORTING INFORMATION:}

The mass spectrometry proteomics data have been deposited to the ProteomeXchange Consortium via the PRIDE ${ }^{17}$ partner repository with the project accession: PXD018066 and PXD016742.

The following supporting information is available free of charge at ACS website http://pubs.acs.org:

Figure S1: Test for protein retention efficiency using BSA assay

FigureS2: BSA-FITC distribution inside the microfluidic device

Figure S3: Fluorescence measurement after BSA-FITC removing by reverse percolation

Figure S4: Proteome coverage of CFP_1 $1 \mu \mathrm{g}$ vs. FAP_10 $\mu \mathrm{g}$ 
Figure S5: Distribution of the yeast proteins identifications among the major cellular compartments

Figure S6: Mass distribution of peptides identifications according to their molecular mass

Figure S7: Normalized distribution of molecular mass of peptides

Figure S8: Normalized distribution peptides identifications according to their Kyte-Doolittle hydrophobicity Index

Figure S9: Distribution of peptide identifications according to the number of missed cleavages

Figure S10: Distribution of proteins among the 12 major subcellular compartments from HT29 cells

Figure S11: Proteome coverage by CFP and FAP methods

Figure S12: Kyte-Doolittle hydrophobicity index of peptides by CFP and FAP

Figure S13: Reproducibility of CFP.

Figure S14: ChipFilter Proteolysis yeast protein extract with different amounts of starting material

Table S1: Capillaries dimensions

Table S2: Detailed description of the microfluidics experimental setup

Table S3: Gene ontology cellular compartments comparison

Table S4: GO cellular compartment of proteins exclusively identified by CFP or FAP treatment 
Table S5: Gene ontology cellular compartment of proteins identified in HT29 cell protein extract C

Table S6.00_Supplementary_tables_description.xlsx

Table S6.01_CFP_1ug_Proteins.xlsx: protein identifications using CFP_1 $\mu \mathrm{g}$ method

Table S6.02_CFP_1ug_Peptides.xlsx: peptide identifications using CFP_1 $\mu$ g method

Table S6.03_CFP_500ng_Proteins.xlsx: protein identifications using CFP_500ng method

Table S6.04_CFP_500ng_Peptides.xlsx: peptide identifications using CFP_500ng method

Table S6.05_FAP_1ug_Proteins.xlsx: protein identifications using overnight FAP $1 \mu \mathrm{g}$ method

Table S6.06_FAP_1ug_Peptides.xlsx: peptide identifications using overnight FAP1 $\mu \mathrm{g}$ method

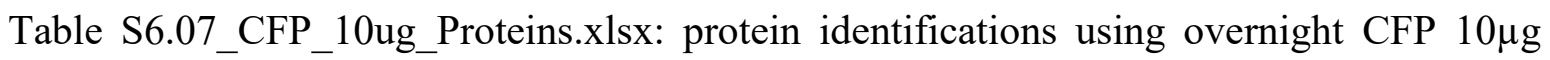
method

Table S6.08_CFP_10ug_Peptides.xlsx: peptide identifications using overnight CFP10 $\mu$ g method

Table S6.09_CFP_28000cells_Proteins.xlsx: protein identifications using CFP_28000cells method

Table S6.10_CFP_28000cells_Peptides.xlsx: peptide identifications using CFP_28000cells method

Table S6.11_FAP_10ug_1H_Proteins.xlsx: protein identifications using 1hour FAP10 $\mu \mathrm{g}$ method 
Table S6.12_FAP_10ug_1H_Peptides.xlsx: peptide identifications using 1hou FAP10 $\mu \mathrm{g}$ method

Table S6.13_FAP_10ug_1H-ON_Proteins.xlsx: protein identifications using overnight/1h FAP10 $\mu$ g method

Table S6.14_FAP_10ug_1H-ON_Peptides.xlsx: peptide identifications using overnight/1h FAP10 $\mu$ g method

Table S6.15_FAP_10ug_ON_Proteins.xlsx: protein identifications using overnight FAP10 $\mu$ g method

Table S6.16_FAP_10ug_ON_Peptides.xlsx: peptide identifications using overnight FAP10 $\mu$ g method

\section{ACKNOWLEDGMENTS}

MMN received a doctoral fellowship from Labex IPGG pour la microfluidique (IPGG 9117), mass spectrometry equipment was subsidized by Conseil Régional d'Île-de-France (Sesame $2010 \mathrm{~N}^{\circ} 10022268$ ) and access to IPGG for microfluidics platform (Equipex CNRS UMS3750). The authors thank Olivier Lesage, Guillaume Laffite, and Bertrand Cinquin from IPGG CNRS UMS3750 for their help in microfluidics design, and Ranjith Kumar from SMBP CNRS FRE2032 for the final proofreading

\section{REFERENCES}

(1) Fujioka, A.; Terai, K.; Itoh, R. E.; Aoki, K.; Nakamura, T.; Kuroda, S.; Nishida, E.; Matsuda, M. Dynamics of the Ras/ERK MAPK Cascade as Monitored by Fluorescent Probes. J. Biol. Chem. 2006, $281 \quad$ (13), 8917-8926. https://doi.org/10.1074/jbc.M509344200. 
(2) Milo, R. What Is the Total Number of Protein Molecules per Cell Volume? A Call to Rethink Some Published Values: Insights \& Perspectives. BioEssays 2013, 35 (12), 1050-1055. https://doi.org/10.1002/bies.201300066.

(3) Zeiler, M.; Straube, W. L.; Lundberg, E.; Uhlen, M.; Mann, M. A Protein Epitope Signature Tag (PrEST) Library Allows SILAC-Based Absolute Quantification and Multiplexed Determination of Protein Copy Numbers in Cell Lines. Molecular \& Cellular Proteomics 2012, 11 (3). https://doi.org/10.1074/mcp.O111.009613.

(4) Xu, K.; Liang, Y.; Piehowski, P. D.; Dou, M.; Schwarz, K. C.; Zhao, R.; Sontag, R. L.; Moore, R. J.; Zhu, Y.; Kelly, R. T. Benchtop-Compatible Sample Processing Workflow for Proteome Profiling of $<100$ Mammalian Cells. Analytical and Bioanalytical Chemistry 2018. https://doi.org/10.1007/s00216-018-1493-9.

(5) Lion, N.; Reymond, F.; Girault, H. H.; Rossier, J. S. Why the Move to Microfluidics for Protein Analysis? Current Opinion in Biotechnology 2004, 15 (1), 31-37. https://doi.org/10.1016/j.copbio.2004.01.001.

(6) deMello, A. J. Control and Detection of Chemical Reactions in Microfluidic Systems. Nature 2006, 442 (7101), 394-402. https://doi.org/10.1038/nature05062.

(7) Brivio, M.; Verboom, W.; N. Reinhoudt, D. Miniaturized Continuous Flow Reaction Vessels: Influence on Chemical Reactions. Lab on a Chip 2006, 6 (3), 329-344. https://doi.org/10.1039/B510856J.

(8) Freire, S. L. S.; Wheeler, A. R. Proteome-on-a-Chip: Mirage, or on the Horizon? Lab on a Chip 2006, 6 (11), 1415. https://doi.org/10.1039/b609871a.

(9) Li, Y.; Yan, L.; Liu, Y.; Qian, K.; Liu, B.; Yang, P.; Liu, B. High-Efficiency Nano/Micro-Reactors for Protein Analysis. RSC Advances 2015, 5 (2), 1331-1342. https://doi.org/10.1039/C4RA12333F.

(10) Gao, J.; Xu, J.; Locascio, L. E.; Lee, C. S. Integrated Microfluidic System Enabling Protein Digestion, Peptide Separation, and Protein Identification. Analytical Chemistry 2001, 73 (11), 2648-2655. https://doi.org/10.1021/ac001126h.

(11) Liuni, P.; Rob, T.; Wilson, D. J. A Microfluidic Reactor for Rapid, Low-Pressure Proteolysis with on-Chip Electrospray Ionization: A Simple Proteolytic Chip for ESIMS. Rapid Communications in Mass Spectrometry 2010, 24 (3), 315-320. https://doi.org/10.1002/rcm.4391.

(12) Kecskemeti, A.; Gaspar, A. Preparation and Characterization of a Packed Bead Immobilized Trypsin Reactor Integrated into a PDMS Microfluidic Chip for Rapid Protein Digestion. Talanta 2017, 166, 275-283. https://doi.org/10.1016/j.talanta.2017.01.060.

(13) Kecskemeti, A.; Nagy, C.; Csosz, E.; Kallo, G.; Gaspar, A. The Application of a Microfluidic Reactor Including Spontaneously Adsorbed Trypsin for Rapid Protein Digestion of Human Tear Samples. PROTEOMICS - Clinical Applications 2017, 11 (11-12), 1700055. https://doi.org/10.1002/prca.201700055.

(14) Zhang, Y.; Fonslow, B. R.; Shan, B.; Baek, M.-C.; Yates, J. R. Protein Analysis by Shotgun/Bottom-up Proteomics. Chemical Reviews 2013, 113 (4), 2343-2394. https://doi.org/10.1021/cr3003533.

(15) Gasilova, N.; Qiao, L.; Momotenko, D.; Pourhaghighi, M. R.; Girault, H. H. Microchip Emitter for Solid-Phase Extraction-Gradient Elution-Mass Spectrometry. Analytical Chemistry 2013, 85 (13), 6254-6263. https://doi.org/10.1021/ac400171e.

(16) Ethier, M.; Hou, W.; Duewel, H. S.; Figeys, D. The Proteomic Reactor: A Microfluidic Device for Processing Minute Amounts of Protein Prior to Mass Spectrometry Analysis. Journal of Proteome Research 2006, 5 (10), 2754-2759. https://doi.org/10.1021/pr060312m. 
(17) Manza, L. L.; Stamer, S. L.; Ham, A.-J. L.; Codreanu, S. G.; Liebler, D. C. Sample Preparation and Digestion for Proteomic Analyses Using Spin Filters. PROTEOMICS 2005, 5 (7), 1742-1745. https://doi.org/10.1002/pmic.200401063.

(18) Wiśniewski, J. R.; Zougman, A.; Nagaraj, N.; Mann, M. Universal Sample Preparation Method for Proteome Analysis. Nature Methods 2009, 6 (5), 359-362. https://doi.org/10.1038/nmeth.1322.

(19) Sielaff, M.; Kuharev, J.; Bohn, T.; Hahlbrock, J.; Bopp, T.; Tenzer, S.; Distler, U. Evaluation of FASP, SP3, and IST Protocols for Proteomic Sample Preparation in the Low Microgram Range. J. Proteome Res. 2017, 16 (11), 4060-4072. https://doi.org/10.1021/acs.jproteome.7b00433.

(20) Zougman, A.; Selby, P. J.; Banks, R. E. Suspension Trapping (STrap) Sample Preparation Method for Bottom-up Proteomics Analysis. PROTEOMICS 2014, 14 (9), 1006-1000. https://doi.org/10.1002/pmic.201300553.

(21) Ludwig, K. R.; Schroll, M. M.; Hummon, A. B. Comparison of In-Solution, FASP, and S-Trap Based Digestion Methods for Bottom-Up Proteomic Studies. J. Proteome Res. 2018, 17 (7), 2480-2490. https://doi.org/10.1021/acs.jproteome.8b00235.

(22) Elagli, A.; Laurette, S.; Treizebre, A.; Bocquet, B.; Froidevaux, R. Diffusion Based Kinetic Selectivity Modulation of Enzymatic Proteolysis in a Microfluidic Reactor: Experimental Analysis and Stochastic Modeling. RSC Adv. 2013, 4 (8), 3873-3882. https://doi.org/10.1039/C3RA46005C.

(23) Nandakumar, M. P.; Marten, M. R. Comparison of Lysis Methods and Preparation Protocols for One- and Two-Dimensional Electrophoresis of Aspergillus Oryzae Intracellular Proteins. ELECTROPHORESIS 2002, 23 (14), 2216-2222. https://doi.org/10.1002/1522-2683(200207)23:14<2216::AID-ELPS2216>3.0.CO;2-Y.

(24) Tyanova, S.; Temu, T.; Sinitcyn, P.; Carlson, A.; Hein, M. Y.; Geiger, T.; Mann, M.; Cox, J. The Perseus Computational Platform for Comprehensive Analysis of (Prote)Omics Data. Nature Methods 2016, 13 (9), 731-740. https://doi.org/10.1038/nmeth.3901.

(25) Osorio, D.; Rondón-Villarreal, P.; Torres, R. Peptides: A Package for Data Mining of Antimicrobial Peptides. The R Journal 2015, 7 (1), 4. https://doi.org/10.32614/RJ-2015001.

(26) Trantidou, T.; Elani, Y.; Parsons, E.; Ces, O. Hydrophilic Surface Modification of PDMS for Droplet Microfluidics Using a Simple, Quick, and Robust Method via PVA Deposition. Microsystems \& Nanoengineering 2017, 3, 16091. https://doi.org/10.1038/micronano.2016.91. 
TABLE OF CONTENTS GRAPHIC For TOC Only

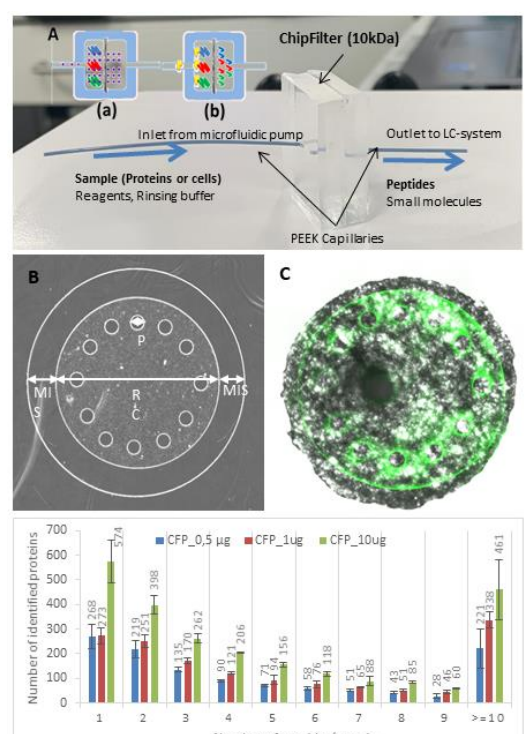

